\title{
Penyerapan Tenaga Kerja pada Sentra Industri Rajutan Binong Jati Kota Bandung
}

\author{
Fina Marliana Darusman \\ Fakultas Ekonomi Universitas Pasundan \\ Jl. Tamansari No. 6 - 8, Bandung 40116 \\ E-Mail: fina.darusman@gmail.com
}

\author{
Endang Rostiana \\ Fakultas Ekonomi Universitas Pasundan \\ J1. Tamansari No. 6 - 8, Bandung 40116 \\ E-Mail: endangrostiana@yahoo.com
}

\begin{abstract}
In order to develop industrial sector, Kota Bandung develop ten industrial and trades areas. One of the industrial and trades area is Binong Jati Knitting Industrial and Trade Centre, which is potentially in absorbing the employment. The objectives of the study are to identify the condition of Binong Jati Knitting Industrial and Trade Centre today and to analyze relationship between labor absorption and several economic variables in Binong Jati Knitting Industrial and Trade Centre. This research use primary data which collected from 55 business unit as a sample from 120 population. Analysis method is descriptive statistic and linier regression. According to our field observation and interview, most of the unit business in Binong Jati Knitting Industrial and Trade Centre is small and middle scale industries. In term of number of employment, Binong Jati Knitting Industrial and Trade Centre is in the second rank after Cibaduyut Shoes Industrial Centre. In recent years, units business and number of workers has decreased. According to regression analysis, in Binong Jati Knitting Industrial and Trade Centre, size of employment is negativelly related with wage rate, positively related with price of raw material, number of sales, labor productivity, and number of machine units.
\end{abstract}

Keywords: labor absorption, wage rate, number of sales, labor productivity, price of raw material, number of machine

\begin{abstract}
ABSTRAK
Dalam upaya pengembangan sektor industri di Kota Bandung, telah ditentukan sepuluh sentra industri. Salah satunya adalah Sentra Industri Rajutan Binong Jati. Sentra Industri Rajutan Binong Jati ini cukup potensial menyerap tenaga kerja. Penelitian ini dilakukan untuk mengetahui bagaimana kondisi Sentra Industri Rajutan Binong Jati saat ini dan menganalisis bagaimana hubungan antara penyerapan tenaga kerja dengan faktor-faktor yang mempengaruhi penyerapan tenaga kerja pada sentra industri tersebut. Sampel penelitian berjumlah 55 unit usaha dari 120 unit usaha yang ada. Metode analisis menggunakan statistik destriptif dan analisis regresi berganda. Hasil pengamatan dan wawancara memperlihatkan dari sisi penyerapan tenaga kerja, Sentra Industri Rajutan Binong Jati merupakan kedua terbanyak setelah Sentra Sepatu Cibaduyut. Di sisi lain, beberapa tahun terakhir Sentra Industri Rajutan Binong Jati menunjukkan penurunan dalam jumlah unit usaha dan pekerja. Hasil analisis menunjukkan bahwa penyerapan tenaga kerja di Sentra Industri Rajutan Binong Jati mempunyai hubungan positif dengan variabel-variabel volume penjualan, produktivitas, harga bahan baku dan jumlah mesin yang dimiliki, serta berhubungan negatif dengan tingkat upah.
\end{abstract}

Kata Kunci: penyerapan tenaga kerja, tingkat upah, volume penjualan, produktivitas tenaga kerja, harga bahan baku, dan modal (mesin). 


\section{PENDAHULUAN}

Kota Bandung sebagai ibu kota Provinsi Jawa Barat merupakan kota terpadat di Jawa Barat. Pada Tahun 2014, Kota Bandung memiliki penduduk sebanyak 2.470.802 jiwa (BPS Kota Bandung, 2014). Dari jumlah penduduk tersebut, jumlah angkatan kerja Kota Bandung sebanyak 1.096.799 orang dengan tingkat partisipasi angkatan kerja sebesar $63,04 \%$.

Penyerapan tenaga kerja terus meningkat seiring dengan meningkatnya investasi dan pertumbuhan ekonomi di Kota Bandung. Hal ini sejalan dengan turunnya jumlah pengangguran terbuka di Kota Bandung. Pada tahun 2014 tingkat pengangguran terbuka menurun menjadi sebesar 8.05\% dibandingkan tahun 2013 yang mencapai 10,98\% (BPS Kota Bandung, 2014).

Laju pertumbuhan ekonomi (LPE) Kota Bandung menunjukkan kenaikan yang positif. Hal ini terlihat dari meningkatnya PDRB Kota Bandung setiap tahunnya, kondisi tersebut membuktikan bahwa kota Bandung mengalami pertumbuhan kegiatan ekonomi. Aktivitas ekonomi Kota Bandung pada beberapa tahun ke depan cenderung positif mengalami pertumbuhan yang cukup signifikan dan LPE nya lebih tinggi dibandingkan dengan LPE Provinsi Jawa Barat dan dapat dilihat pada Tabel 1.

Tabel 1. PDRB dan Laju Pertumbuhan Ekonomi (LPE) Kota Bandung Tahun 2008-2012

\begin{tabular}{|c|c|c|}
\hline Tahun & $\begin{array}{c}\text { PDRB } \\
\text { (Harga Konstan 2000/Jt Rp) }\end{array}$ & $\begin{array}{l}\text { LPE } \\
\text { (\%) }\end{array}$ \\
\hline 2008 & 26.978.909 & 8,17 \\
\hline 2009 & 29.228 .272 & 8,34 \\
\hline 2010 & 31.697 .282 & 8,45 \\
\hline 2011 & 34.415 .522 & 8,73 \\
\hline 2012 & 37.558 .320 & 8,98 \\
\hline 2012 & LPE Provinsi Jawa Barat & 6,20 \\
\hline
\end{tabular}

Sumber: BPS Kota Bandung (diolah)

Pertumbuhan ekonomi Kota Bandung didukung oleh sektor-sektor industri pengolahan, perdagangan dan jasa yang paling tinggi kontribusinya pada perekonomian Kota Bandung. Pembangunan sektor industri diharapkan mampu menyerap tenaga kerja, baik yang pindah dari sektor pertanian maupun yang baru memasuki pasar kerja. Dalam upaya pengembangan sektor industri di Kota Bandung maka telah ditentukan beberapa sentra industri yang tertuang dalam surat keputusan Walikota Bandung Nomor 530/Kep.295 DISKUKM.PERINDAG/2009. Dalam surat keputusan tersebut disebutkan bahwa terdapat 10 sentra usaha mikro, kecil dan menengah (UMKM) di Kota Bandung yaitu: 1) Sentra Sepatu Cibaduyut, 2) Sentra Rajut Binong Jati, 3) Sentra Jeans Cihampelas, 4) Sentra Tekstil dan Produk Tekstil Cigondewah, 5) Sentra Kaos dan Sablon, 6) Sentra Tahu dan Tempe Cibuntu, 7) Sentra Spare Part Otomotif Kiaracondong, 8) Sentra Boneka Sukamulya, 9) Sentra Boneka Warung Muncang, dan 10) Sentra Tas Leuwipanjang.

Sentra Industri Rajutan Binong Jati merupakan salah satu sentra industri kecil yang cukup potensial dalam penyerapan tenaga kerja dan kontribusinya terhadap perekonomian Kota Bandung. Pada tahun 2012 dengan unit usaha sebanyak 293 tenaga kerja yang terserap yaitu sebanyak 2143 orang. Sentra Industri Rajutan Binong Jati menempati posisi kedua terbanyak dalam penyerapan tenaga kerja setelah sentra sepatu Cibaduyut dan beberapa sentra industri yang lainnya.

Sentra rajutan Binong Jati terletak di wilayah Kecamatan Batununggal, khususnya di Kelurahan Binong. Usaha rajutan di Kelurahan Binong sudah dimulai sejak tahun 1965. Pada awal Tahun 1975, jumlah perusahaan rajut yang ada hanya 3 unit usaha. Namun karena permintaan produk rajutan semakin meningkat, maka penduduk lainnya tertarik untuk mengembangkan usaha rajut tersebut. Pada akhirnya, di tahun 1999 jumlah usaha rajut di kawasan Binong berkembang menjadi 225 unit usaha. Sebelum krisis ekonomi, kampung ini dan beberapa kampung di sekitarnya mencapai masa keemasan dengan memiliki 1.745 tenaga kerja (Al Farisi, 2013).

Adanya Sentra Industri Rajutan Binong Jati telah membuka lapangan pekerjaan bagi masyarakat sekitar. Kemunculan Sentra Industri Rajutan Binong Jati memerlukan juga tenaga kerja yang banyak serta terampil dalam membuat rajutan. Tenaga kerja merupakan sumber daya utama dalam sebuah produksi. Sentra Industri Rajutan Binong Jati merupakan industri yang bersifat padat karya. Oleh karena itu industri ini mampu menyerap banyak tenaga kerja. 
Tabel 2. Jumlah Unit Usaha dan Jumlah Tenaga Kerja di Sentra Industri Rajutan Binong Jati

\begin{tabular}{ccc}
\hline Tahun & $\begin{array}{c}\text { Jumlah Usaha } \\
\text { (Unit Usaha) }\end{array}$ & $\begin{array}{c}\text { Jumlah Pekerja } \\
\text { (Jiwa) }\end{array}$ \\
\hline 2012 & 293 & 2143 \\
2013 & 140 & 1680 \\
2014 & 120 & 1440 \\
\hline
\end{tabular}

Sumber: Koperasi Sentra Industri Rajutan Binong Jati (KIRB)

Walaupun dalam sifat produksinya Sentra Industri Rajutan Binong Jati bersifat padat karya, namun dalam perkembangannya saat ini, jumlah tenaga kerja yang terserap pada sentra industri ini menunjukkan penurunan. Penurunan jumlah tenaga kerja yang terserap ini tidak terlepas dari kondisi Sentra Industri Rajutan Binong Jati itu sendiri yang dari sisi jumlah unit usaha juga terus menurun, dapat dilihat pada Tabel 3 .

Tabel 3. Jumlah Unit Usaha dan Jumlah Tenaga Kerja di Sentra Industri Rajutan Binong Jati

\begin{tabular}{crr}
\hline Tahun & $\begin{array}{c}\text { Jumlah Usaha } \\
\text { (Unit Usaha) }\end{array}$ & $\begin{array}{c}\text { Jumlah Pekerja } \\
\text { (Jiwa) }\end{array}$ \\
\hline 2012 & 293 & 2.143 \\
2013 & 140 & 1.680 \\
2014 & 120 & 1.440 \\
\hline
\end{tabular}

Sumber: Koperasi Sentra Industri Rajutan Binong Jati

Penurunan jumlah tenaga kerja yang terserap pada satu unit usaha dapat dipengaruhi oleh banyak hal. Berdasarkan teori permintaan tenaga kerja, perubahan permintaan tenaga kerja dapat terjadi karena adanya perubahan pada faktor upah dan faktor selain upah (Simanjuntak, 2007). Perubahan tingkat upah akan mempengaruhi penyerapan tenaga kerja, dengan semakin tinggi tingkat upah maka pihak perusahaan akan mengurangi jumlah permintaan tenaga kerja. Dengan demikian adanya hubungan negatif yang terjadi antara tingkat upah dengan permintaan tenaga kerja.

Permintaan tenaga kerja bersifat derived demand, yaitu permintaan yang ditentukan oleh permintaan lainnya. Permintaan tenaga kerja ditentukan oleh permintaan barang-barang atau output yang diproduksinya. Semakin banyak permintaan output hasil produksi, maka semakin banyak permintaan tenaga kerjanya.
Dalam beberapa penelitian sebelumnya yang menggunakan objek penelitian para pengusha kecil dan menengah di beberapa daerah di Indonesia dan di luar negeri, disebutkan bahwa faktor-faktor yang mempengaruhi penyerapan tenaga kerja pada industri kecil selain faktor upah terdapat faktor-faktor lainnya di antaranya adalah nilai penjualan (nilai produksi), modal kerja, produktivitas tenaga kerja, dan harga bahan baku.

Penelitian Yanuwardani dan Woyanti (2009) pada usaha kecil menengah tempe di Kota Semarang, penelitian Purnomo (2013) pada usaha kecil menengah anyaman bambu di Kabupaten Banyuwangi, dan penelitian Budiawan (2013) pada industri kecil pengolahan ikan di Kabupaten Demak, ketiganya menggunakan variabel modal kerja, nilai produksi dan tingkat upah sebagai variabel bebas yang mempengaruhi penyerapan tenaga kerja pada ketiga penelitian tersebut. Penelitian sejenis lainnya membahas bahwa selain faktor upah, faktor lainnya adalah modal kerja, bahan baku, dan nilai produksi (Adrianto, 2013). Penelitian Siburian dan Woyanti (2013) memasukkan faktor upah, modal kerja, produktivitas tenaga kerja, dan usia perusahaan sebagai faktor-faktor yang mempengaruhi penyerapan tenaga kerja pada industri kecil dan menengah furniture kayu di Kabupaten Jepara. Penelitian yang dilakukan pada sektor pertanian di Nigeria menggunakan variabel-variabel upah pekerja, jumlah produksi, harga produk pertanian yang dijual, luas lahan pertanian, serta biaya produksi lainnya sebagai faktor-faktor yang mempengaruhi pernyerapan tenaga kerja pada sektor pertanian tersebut (Odoemenem dan Odom, 2010). Penelitian penyerapan tenaga kerja pada sektor pertanian lainnya adalah penelitian Biniaz et al. (2014). Penelitian ini menggunakan variabel tingkat upah, harga produk pertanian, dan luas lahan pertanian sebagai variabel-variabel yang mempengaruhi tingkat elastisitas permintaan tenaga kerja pada sektor pertanian di Provinsi Kohgiluyeh and Boyer-Ahmad, Iran.

Berdasarkan kepada teori permintaan dan beberapa penelitian sejenis sebelumnya, dalam penelitian ini akan dianalisis bagaimana pengaruh faktor upah dan faktor selain upah, yaitu produktivitas tenaga kerja, nilai penjualan produk, dan modal terhadap penyerapan tenaga kerja di Sentra Industri Rajutan Binong Jati. Berbeda dengan penelitianpenelitian sejenis yang menjadi rujukan penelitian 
ini, variabel harga bahan baku dalam penelitian ini menggunakan variabel dummy untuk menggambarkan adanya perbedaan harga beli bahan baku yang ditentukan berdasarkan cara pembelian bahan baku tersebut. Bahan baku dapat dibeli secara kredit atau secara tunai dengan harga yang berbeda. Penggunaan variabel dummy ini juga sebagai pertimbangan bahwa pada penelitian ini menggunakan data primer yang bersifat cross section bukan data runtut waktu (time series). Oleh karena itu untuk data harga bahan baku tidak dapat dilihat bagaiman perkembangan tingkat harganya dalam beberapa periode, namun hanya dapat diketahui tingkat harga pada saat survei dilakukan saja.

\section{METODE}

Metode penelitian yang digunakan dalam penelitian ini adalah metode deskriptif kuantitatif. Metode deskriptif dipakai untuk menggambarkan mengenai kondisi Sentra Industri Rajutan Binong Jati saat ini dilihat dari seberapa banyak jumlah perusahaan rajut saat ini, dan berapa banyak tenaga kerja yang terserap. Metode kuantitatif dengan menggunakan analisis regresi linier berganda digunakan untuk mengetahui bagaimana hubungan antara tingkat upah, volume penjualan, harga bahan baku, produktivitas tenaga kerja, dan modal dengan penyerapan tenaga kerja pada Sentra Industri Rajutan Binong Jati.

\section{Jenis dan Sumber Data}

Jenis dan sumber data yang diperoleh adalah data sekunder dan primer. Data primer, yaitu data yang diperoleh melalui wawancara dengan responden yang relevan dengan survei lapangan (kuesioner). Adapun data primer yang digunakan dalam penelitian ini dikumpulkan melalui pengisian kuesioner oleh responden, sedangkan data sekunder yaitu data yang diperoleh dari lembaga pengumpul data. Adapun data sekunder yang digunakan dalam penelitian ini diperoleh dari Badan Pusat Statistik Provinsi Jawa Barat, Badan Pusat Statistik Kota Bandung, Kantor Kecamatan Batununggal, Kantor Kelurahan Binong, dan Koperasi Sentra Industri Rajutan Binong Jati.

\section{Populasi dan Sampel}

Populasi dalam penelitian ini adalah seluruh pemilik industri rajutan di kawasan Binong. Jumlah populasi dari pemilik unit usaha yang ada di Sentra Industri Rajutan Binong Jati sebanyak 120 unit usaha (Koperasi Industri Rajutan Bonong Jati, 2015). Pengambilan sampel yang digunakan dalam penelitian adalah pengambilan sampel secara acak sederhana (Simple Random Sampling) dengan jumlah sampel dihitung menggunakan rumus Slovin (Umar, 2011). Perhitungan jumlah sampel penelitian adalah sebagai berikut:

$$
n=\frac{N}{1+N(e)^{2}}
$$

di mana:

$$
\begin{aligned}
\mathrm{n}= & \text { Ukuran sampel } \\
\mathrm{N}= & \text { Ukuran populasi } \\
\mathrm{e}= & \text { Persen kelonggaran ketidak telitian karena } \\
& \text { kesalahan pengambilan }
\end{aligned}
$$

Dengan jumlah populasi sebanyak 120 unit usaha dan faktor kesalahan sebesar 10 persen, maka jumlah sampel penelitian adalah sebanyak:

$$
\begin{aligned}
n & =\frac{120}{1+120(0,10)^{2}} \\
& =54,5 \text { unit usaha }
\end{aligned}
$$

\section{Model Analisis Data}

Alat analisis yang digunakan untuk mengetahui bagaimana hubungan antara variabel-variabel tingkat upah, volume penjualan, harga bahan baku, produktivitas tenaga kerja, dan modal usaha dengan penyerapan tenaga kerja pada Sentra Industri Rajutan Binong Jati adalah analisis regresi berganda dengan metode Ordinary Least Square (OLS). Variabel penyerapan tenaga kerja sebagai variabel terikat (dependent variable). Variabel bebasnya (independent variable) terdiri dari upah, volume penjualan, harga bahan baku, produktivitas tenaga kerja, dan modal usaha.

Fungsi persamaan penyerapan tenaga kerja yang digunakan dalam penelitian ini adalah:

$\mathrm{Y}=\mathrm{f}(\mathrm{W}, \mathrm{V}, \mathrm{P}, \mathrm{F}, \mathrm{M})$

Keterangan:

$\mathrm{Y}=$ Jumlah penyerapan tenaga kerja (Orang)

$\mathrm{W}=$ Tingkat upah $(\mathrm{Rp} /$ Orang/Bulan $)$

$\mathrm{V}=$ Volume penjualan (Lusin/Bulan)

$\mathrm{P}=$ Harga bahan baku (Rp/unit)

$\mathrm{F}=$ Produktivitas (Lusin/Orang/Bulan)

$\mathrm{M}=$ Modal (Unit)

Untuk analisis dengan menggunakan regresi, maka persamaan (1) tersebut ditransformasi menjadi persamaan regresi dalam bentuk logaritma natural, 
dengan tujuan agar supaya analisis dapat dilakukan dengan menggunakan konsep elastisitas. Adapun model regresi berganda dalam penelitian ini adalah sebagai berikut.

$$
\begin{aligned}
\mathrm{LY}= & \beta \mathrm{o}+\beta 1 \mathrm{LW}+\beta 2 \mathrm{LV}+\beta 3 \mathrm{P}+\beta 4 \mathrm{LF}+\beta 5 \mathrm{LM} \\
& +\mathrm{e} \ldots \ldots \ldots \ldots \ldots \ldots \ldots \ldots \ldots \ldots \ldots \ldots \ldots \ldots \ldots \ldots \ldots \ldots \ldots \ldots \ldots \ldots \ldots \ldots \ldots \ldots \ldots \ldots \ldots \ldots \ldots \ldots \ldots \ldots \ldots \ldots \ldots
\end{aligned}
$$

Keterangan:

$\mathrm{L}=$ Logaritma natural

$\mathrm{Y}=$ Jumlah penyerapan tenaga kerja (Orang)

$\mathrm{W}=$ Tingkat upah (Rp/Orang/Bulan)

$\mathrm{V}=$ Volume penjualan (Lusin/Bulan)

$\mathrm{P}=$ Harga bahan baku (Dummy variable)

$\mathrm{F}=$ Produktivitas (Lusin/Orang/Bulan)

$\mathrm{M}=$ Modal (Unit)

$\beta \mathrm{o}=$ Konstanta

$\beta 1, \beta 2, \beta 3, \beta 4=$ Koefisien elastistias variabel bebas

$e=$ error term

\section{Definisi dan Operasionalisasi Variabel}

Variabel terikat yang dianalisis dalam penelitian ini adalah jumlah penyerapan tenaga kerja dengan lima variabel bebas, yaitu tingkat upah, volume penjualan, harga bahan produktivitas, tenaga kerja, dan modal usaha. Bagaimana penjelasan operasional setiap variabel bebas maupun variabel terikat dapat dilihat pada Tabel 4.

\section{Hipotesis Penelitian}

Penyerapan tenaga kerja merupakan jumlah tenaga kerja yang bekerja dalam suatu unit usaha. Sedikit banyaknya tenaga kerja yang terserap oleh suatu unit usaha dipengaruhi oleh dua faktor yaitu faktor upah dan faktor non upah, yaitu volume penjualan, produktivitas, harga bahan baku, serta modal usaha. Bagaimana hubungan antara jumlah penyerapan tenaga kerja sebagai variabel terikat dengan variabel-variabel bebasnya dihipotesiskan sebagai berikut: (1) diduga terdapat pengaruh negatif tingkat upah terhadap penyerapan tenaga kerja pada Sentra Industri Rajutan Binong Jati di Kota Bandung, (2) diduga terdapat pengaruh positif volume penjualan terhadap penyerapan tenaga kerja pada Sentra Industri Rajutan Binong Jati di Kota Bandung, (3) diduga terdapat perbedaan jumlah penyerapan tenaga kerja pada unit usaha di Sentra Industri Rajutan Binong Jati yang membeli bahan baku secara tunai dengan unit usaha yang membeli bahan baku secara kredit, (4) diduga terdapat pengaruh positif produktivitas tenaga kerja terhadap penyerapan tenaga kerja pada Sentra Industri Rajutan Binong Jati di Kota Bandung, dan (5) diduga terdapat pengaruh positif pada penggunaan modal usaha terhadap penyerapan tenaga kerja pada Sentra Industri Rajutan Binong Jati di Kota Bandung.

\begin{tabular}{|c|c|c|c|}
\hline No & Nama Variabel & Operasionalisasi Variabel & Satuan Variabel \\
\hline 1 & $\begin{array}{l}\text { Penyerapan Tenaga Kerja } \\
\text { (Y) }\end{array}$ & $\begin{array}{l}\text { Penyerapan tenaga kerja adalah banyaknya tenaga kerja pada } \\
\text { unit-unit usaha Sentra Industri Rajutan Binong Jati. Tenaga kerja } \\
\text { yang di hitung merupakan tenaga kerja yang benar-benar diberi } \\
\text { dibayar atau diberi upah. }\end{array}$ & Orang \\
\hline 2 & Tingkat Upah (W) & $\begin{array}{l}\text { Tingkat upah adalah semua pengeluaran uang yang dibayarkan } \\
\text { kepada pekerja sebagai imbalan atas pekerjaan atau jasa yang } \\
\text { telah atau akan dilakukan pada setiap periodenya. Tingkat upah } \\
\text { yang diambil merupakan upah rata-rata setiap pekerja. }\end{array}$ & Rp/Orang/Bulan \\
\hline 3 & Volume Penjualan (V) & $\begin{array}{l}\text { Volume penjualan merupakan jumlah unit rajutan yang dijual } \\
\text { oleh unit-unit usaha rajutan Binong Jati pada satu periode. }\end{array}$ & Lusin/Bulan \\
\hline 4 & Harga Bahan Baku (P) & $\begin{array}{l}\text { Harga bahan baku dalam penelitian ini merupakan harga atas } \\
\text { bahan baku berupa benang untuk menunjang produksi rajut. } \\
\text { Perbedaan harga bahan baku dapat dilihat apakah produsen } \\
\text { membeli harga bahan baku secara tunai atau secara kredit. }\end{array}$ & $\begin{array}{l}\text { Dummy } \\
1=\text { Membayar secara tunai } \\
0=\text { Membayar membayar } \\
\text { secara kredit }\end{array}$ \\
\hline 5 & $\begin{array}{l}\text { Produktivitas Tenaga Kerja } \\
\text { (F) }\end{array}$ & $\begin{array}{l}\text { Produktivitas Tenaga Kerja adalah nilai produksi rata-rata (dalam } \\
\text { unit barang) yang dapat dihasilkan oleh satu orang tenaga kerja } \\
\text { setiap bulannya. }\end{array}$ & Lusin/Orang/ Bulan \\
\hline 6 & Modal (Mesin) (M) & Modal adalah jumlah unit mesin yang dimiliki setiap unit usaha & Unit/Unit Usaha \\
\hline
\end{tabular}

Tabel 4. Operasionalisasi Variabel 


\section{HASIL}

Berdasarkan hasil wawancara dengan pengurus Koperasi Sentra Industri Rajutan Binong Jati (KIRBI), awalnya Sentra Industri Rajutan Binong Jati adalah usaha yang dilakukan secara turun temurun dan dimulai sejak tahun 1960-an oleh beberapa orang warga Binong Jati yang pernah bekerja di perusahaan pabrik rajutan milik pengusaha Tionghoa di Kota Bandung. Berbekal keterampilan yang dimilikinya, akhirnya mereka mulai membuka usaha serupa di wilayah tempat tinggal mereka yaitu di Binong Jati sebagai industri rumah tangga. Pada mulanya usaha ini hanya ditekuni oleh beberapa orang saja hingga akhirnya mulai berkembang hingga saat ini dan memberikan dampak bagi perekonomian masyarakat yang semula hanya tergantung pada sektor pertanian.

Untuk melihat bagaimana kondisi di Sentra Industri Rajutan Binong Jati dapat dilakukan dengan melihat persentase rata-rata jumlah tenaga kerja, tingkat pendidikan para tenaga kerja, produktivitas tenaga kerja, jumlah mesin, serta volume penjualan dari 55 unit usaha yang dijadikan sampel penelitian.

Rata-rata jumlah tenaga kerja yang digunakan dalam satu unit usaha rajut di Sentra Industri Rajutan Binong Jati, 55\% unit usaha umumnya menggunakan tenaga kerja sebanyak 5 hingga 10 orang tenaga kerja. Serta untuk beberapa perusahaan lainnya yang menggunakan tenaga kerja 11 hingga 15 orang $(22 \%)$, 16 hingga 20 orang tenaga kerja $(9 \%)$ dan sisanya sebesar $14 \%$ perusahaan menggunakan tenaga kerja diatas 20 orang (Tabel 5.).

Tabel 5. Jumlah Tenaga Kerja Per Unit Usaha Sentra Industri Rajutan Binong Jati Pada Juni 2015

\begin{tabular}{ccc}
\hline $\begin{array}{c}\text { Jumlah Tenaga Kerja } \\
\text { (Orang) }\end{array}$ & $\begin{array}{c}\text { Jumlah Perusahaan } \\
\text { (Unit Usaha) }\end{array}$ & Persentase \\
\hline $5-10$ & 30 & $55 \%$ \\
$11-15$ & 12 & $22 \%$ \\
$16-20$ & 5 & $9 \%$ \\
$>20$ & 8 & $14 \%$ \\
Jumlah & $\mathbf{5 5}$ & $\mathbf{1 0 0} \%$ \\
\hline
\end{tabular}

Sumber: Data Primer, diolah Juli 2015

Pada Tabel 6. terlihat bahwa mayoritas pekerja pada Sentra Industri Rajutan Binong Jati adalah lulusan SLTA.
Tabel 6. Persentase Rata-Rata Tingkat Pendidikan Pekerja pada Sentra Industri Rajutan Binong Jati

\begin{tabular}{ccc}
\hline Tingkat Pendidikan & Jumlah Perusahaan & Persentase \\
\hline SD & - & - \\
SLTP & 26 & $47 \%$ \\
SLTA & 29 & $53 \%$ \\
>SLTA & - & - \\
Jumlah & 55 & $100 \%$ \\
\hline
\end{tabular}

Sumber: Data Primer, diolah Juli 2015

Dari 55 unit usaha yang dijadikan sampel, rata-rata tingkat produktivitas tenaga kerjannya sangat berbeda (Tabel 7.). Dalam menghasilkan produknya kebanyakan para tenaga kerjanya mampu menghasilkan sekitar 6-15 lusin per orang per bulan. Namun ada pula beberapa perusahaan memiliki tenaga kerja yang mampu menghasilkan sekitar 16-25 lusin per orang per bulan, bahkan ada tiga unit usaha yang pekerjanya mampu menghasilkan dari 26-35 lusin per orang per bulan.

Tabel 7. Rata-Rata Produktivitas Tenaga Kerja Setiap Perusahaan

\begin{tabular}{cc}
\hline $\begin{array}{c}\text { Produktivitas Tenaga Kerja } \\
\text { (Lusin/Orang/Bulan) }\end{array}$ & $\begin{array}{c}\text { Jumlah Perusahaan } \\
\text { (Unit Usaha) }\end{array}$ \\
\hline $6-15$ & 32 \\
$16-25$ & 20 \\
$26-35$ & 3 \\
Jumlah & 55 \\
\hline
\end{tabular}

Sumber: Data Primer, diolah Juli 2015

Berdasarkan jumlah unit mesin yang dipergunakan, sebagian besar unit usaha yang ada di Sentra Industri Rajutan Binong Jati menggunakan mesin sebanyak 1-7 unit sebanyak $42 \%$ dan perusahaan menggunakan 8-14 unit sebanyak (40\%), sedangkan sebagian kecil saja yang menggunakan mesin lebih dari 15 unit (Tabel 8.).

Tingkat penjualan setiap unit usaha di Sentra Industri Rajutan Binong Jati berbeda satu dengan lainnya. Tabel 9. Memperlihatkan bahwa dari 55 unit usaha yang dijadikan sampel, 22 unit usaha (40\%) menjual sebanyak 50-140 lusin per bulan, 33\% unit usaha menjual sebanyak 141-240 lusin per bulan, sisanya sebanyak $27 \%$ unit usaha menjual lebih dari 240 lusin per bulannya. 
Tabel 8. Jumlah Mesin Yang Dimiliki Unit Usaha di Sentra Industri Rajutan Binong Jati

\begin{tabular}{ccc}
\hline $\begin{array}{c}\text { Jumlah Mesin } \\
\text { (Unit) }\end{array}$ & $\begin{array}{c}\text { Jumlah Usaha } \\
\text { (Unit) }\end{array}$ & Presentase \\
\hline $\mathbf{1 - 7}$ & 23 & $42 \%$ \\
$\mathbf{8 - 1 4}$ & 22 & $40 \%$ \\
$\mathbf{1 5 - 2 1}$ & 4 & $7 \%$ \\
$>\mathbf{2 1}$ & 6 & $11 \%$ \\
Jumlah & $\mathbf{5 5}$ & $\mathbf{1 0 0} \%$ \\
\hline
\end{tabular}

Sumber: Data Primer, diolah Juli 2015

Tabel 9. Rata-Rata Volume Penjualan di Sentra Industri Rajutan Binong Jati

\begin{tabular}{ccc}
\hline $\begin{array}{c}\text { Volume Penjualan } \\
\text { (Lusin/Bulan) }\end{array}$ & Jumlah Perusahaan & \% \\
\hline $50-140$ & 22 & 40 \\
$141-240$ & 18 & 33 \\
$>240$ & 15 & 27 \\
Jumlah & $\mathbf{5 5}$ & $\mathbf{1 0 0}$ \\
\hline
\end{tabular}

Sumber: Data Primer, diolah Juli 2015

\section{Hasil Regresi}

Hasil perhitungan regresi dengan model regresi natural logaritma, variabel terikat jumlah penyerapan tenaga kerja (Y), dan variabel bebas tingkat upah $(\mathrm{W})$, volume penjualan (V), harga bahan baku (P), produktivitas (F), dan jumlah mesin (M) dapat dilihat pada Tabel 10.

Tabel 10. Hasil Regresi Linier Berganda

\begin{tabular}{lrrr}
\hline \multicolumn{1}{c}{ Variabel } & Coefficient & \multicolumn{1}{c}{ t-Statistic } & \multicolumn{1}{c}{ Prob } \\
\hline C & 0.267887 & 0.548280 & 0.5860 \\
LW & -0.018468 & -0.525833 & 0.6014 \\
LV & 0.974638 & 62.64502 & 0.0000 \\
P & 0.004747 & 0.549828 & 0.5849 \\
LF & -0.978400 & -57.37081 & 0.0000 \\
LM & 0.030903 & 2.195422 & 0.0329 \\
\hline \multicolumn{4}{c}{0.998993} \\
& R-Squared & 9719.726 \\
\end{tabular}

Sumber: Hasil pengolahan data
Dari hasil estimasi regresi tersebut, maka dapat ditulis suatu persamaan regresi sebagai berikut:

$$
\begin{aligned}
\mathrm{LY}= & 0,267887-0,018468 \mathrm{LW}+0,974638 \mathrm{LV} \\
& +0,004747 \mathrm{P}-0,978400 \mathrm{LF}+0,030903 \mathrm{LM}
\end{aligned}
$$

Agar persamaan hasil regresi tersebut dapat dijadikan dasar analisis selanjutnya, maka terlebih dahulu harus dilakukan pengujian, baik pengujian asumsi klasik maupun pengujian statistik.

\section{Pengujian Asumsi Klasik}

Pengujian asumsi klasik yang pertama adalah pengujian ada tidaknya gejala autokorelasi dalam model regresi. Dengan tingkat signifikasi $(\alpha=$ 0,05 ), nilai $\mathrm{k}=5$ dan jumlah observasi banyak 55 maka diperoleh nilai $\mathrm{d}_{\mathrm{L}}$ sebesar 1,374 dan batas atas $\mathrm{d}_{u}$ sebesar 1,768. Nilai DW-stat dari hasil regresi menunjukkan nilai sebesar 1.906. Dengan demikian nilai -stat tersebut terletak diantara $\mathrm{d}_{\mathrm{u}}$ dan $\mathrm{d}_{\mathrm{L}}$, atau ada di daerah bebas autokorelasi, sehingga dapat disimpulkan bahwa dalam model regresi tidak terdapat gejala autokorelasi.

Pengujian asumsi klasik yang kedua adalah pengujian ada tidaknya gejala Heteroskedastisitas. Untuk menentukan apakah terjadi heteroskedastisitas dalam model ini maka dilakukan uji dengan menggunakan uji white. Terdapat heteroskedastisitas apabila dari hasil uji nilai probabilitasnya lebih besar dari alfa 5\% $(\alpha=0,05)$. Adapun hasil uji heteroskedastisitas dapat dilihat pada Tabel 11.

Tabel 11. Hasil Uji Heteroskedastisitas dengan Uji White

\begin{tabular}{llll}
\hline F-statistic & 1.479 .856 & Prob. $F(19,35)$ & 0.1540 \\
Obs*R-squared & 2.450 .122 & Prob. Chi-Square(19) & 0.1776 \\
Scaled explained SS & 2.165 .435 & Prob. Chi-Square(19) & 0.3018
\end{tabular}

Sumber: Hasil pengolahan data

Ada tidaknya masalah heteroskedastisitas dapat dilihat dari nilai probabilitas chi-square sebesar 0,177 $(17,7 \%)$ lebih besar dari $\alpha=5 \%$ yang berarti tidak terdapat heteroskedastisitas dalam model regresi.

Uji asumsi klasik yang terakhir adalah uji multikolinearitas. Ada tidaknya multikolinearitas dapat diketahui atau dilihat dari koefisien kolerasi masing-masing variabel bebas. Jika nilai koefisien korelasi masing-masing variabel bebas lebih besar dari 0,8 maka terjadi multikolinearitas. 
Tabel 12. Hasil Koefisien Korelasi

\begin{tabular}{cccccc}
\hline & LW & LV & P & LF & LM \\
\hline LW & 1.000 .000 & 0.558978 & 0.083624 & 0.408397 & 0.439895 \\
LV & 0.558978 & 1.000 .000 & -0.035702 & 0.600757 & 0.851516 \\
$\mathbf{P}$ & 0.083624 & -0.035702 & 1.000 .000 & -0.083464 & 0.039332 \\
LF & 0.408397 & 0.600757 & -0.083464 & 1.000 .000 & 0.166334 \\
LM & 0.439895 & 0.851516 & 0.039332 & 0.166334 & 1.000 .000 \\
\hline
\end{tabular}

Sumber: Hasil pengolahan data

Tabel 12. merupakan hasil pengujian multikolinearitas dengan Uji Correlatio. Berdasarkan hasil koefisien korelasi masing-masing variabel bebas terdapat nilai yang lebih besar dari 0,8 , berarti terdapat gejala multikolinearitas. Oleh karena itu perlu dilakukan pengujian lainnya, yaitu dengan menggunakan pengujian pendekatan korelasi parsial (metode Farrar-Glauber) dengan tahapan sebagai berikut:

1) Regresi kembali $L Y=\beta o+\beta 1 L W+\beta 2 L V+\beta 3 P$

$$
+\beta 4 \mathrm{LF}+\beta 5 \mathrm{LM}
$$

2) Lakukan estimasi untuk:

$$
\begin{aligned}
& \mathrm{LW}=\beta \mathrm{o}+\beta 2 \mathrm{LV}+\beta 3 \mathrm{P}+\beta 4 \mathrm{LF}+\beta 5 \mathrm{LM} \ldots . .(\mathrm{R} 2) \\
& \mathrm{LV}=\beta \mathrm{o}+\beta 1 \mathrm{LW}+\beta 3 \mathrm{P}+\beta 4 \mathrm{LF}+\beta 5 \mathrm{LM} \ldots(\mathrm{R} 3) \\
& \mathrm{P}=\beta \mathrm{o}+\beta 1 \mathrm{LV}+\beta 2 \mathrm{LW}+\beta 4 \mathrm{LF}+\beta 5 \mathrm{LM} \ldots(\mathrm{R} 4) \\
& \mathrm{LF}=\beta \mathrm{o}+\beta 1 \mathrm{P}+\beta 2 \mathrm{LV}+\beta 3 \mathrm{LW}+\beta 5 \mathrm{LM} \ldots . .(\mathrm{R} 5) \\
& \mathrm{LM}=\beta \mathrm{o}+\beta 1 \mathrm{LW}+\beta 2 \mathrm{LV}+\beta 3 \mathrm{P}+\beta 4 \mathrm{LF} \ldots . .(\mathrm{R} 6)
\end{aligned}
$$

Ketentuan pengujian: jika R1 > R2, R3, R4, R5 maka dalam model tidak ditemukan adanya multikolineritas dan jika R1 < R2, R3, R4, R5 maka dalam model ditemukan adanya multikolineritas.

Tabel 13. berikut adalah perbandingan nilai $R$-square untuk regresi model keseluruhan (R1) dengan regresi antar variabel bebasnya (R2, R3, R4, dan R5).

Tabel 13. Perbandingan Nilai R-Square

\begin{tabular}{cc}
\hline Persamaan Model Regresi & Nilai $R$-square \\
\hline R1 & 0,9989 \\
R2 & 0,3333 \\
R3 & 0,9438 \\
R4 & 0,0397 \\
R5 & 0,7959 \\
R6 & 0,9128 \\
\hline
\end{tabular}

Sumber: Hasil pengolahan data
Hasil pengujian menunjukan bahwa nilai R1 $>\mathrm{R} 2, \mathrm{R} 3, \mathrm{R} 4, \mathrm{R} 5, \mathrm{R} 6$, dengan demikian dapat disimpulkan bahwa dalam model tidak ditemukan adanya gejala multikolinearitas.

\section{Pengujian Statistik}

Setelah pengujian asumsi klasik, selanjutnya adalah pengujian statistika, yang terdiri dari uji-t, uji-F, dan R-square. Tabel 14. memperlihatkan hasil uji-t. Dari hasil tersebut terlihat bahwa untuk variabel volume penjualan, produktivitas tenaga kerja, dan jumlah modal memiliki nilai t-stat yang lebih besar dari t-tabel, maka ketiga variabel tersebut secara parsial signifikan berpengaruh terhadap penyerapan tenaga kerja di Sentra Industri Rajutan Binong Jati. Dua varaibel bebas lainnya, yaitu upah dan harga bahan baku nilai t-statnya lebih kecil dari t-tabel, sehingga kedua variabel tersebut secara masingmasing tidak berpengaruh secara signifikan terhadap penyerapan tenaga kerja.

Tabel 14. Hasil Uji T-Statistik

\begin{tabular}{cccc}
\hline Variabel & t-stat & t-tabel $(\mathbf{a}=\mathbf{0 , 0 5})$ & Keterangan \\
\hline LW & -0.525833 & -2.009 & Tidak Signifikan \\
LV & 62.64502 & 2.009 & Signifikan \\
P & 0.549828 & 2.009 & Tidak Signifikan \\
LF & -57.37081 & -2.009 & Signifikan \\
LM & 2.195422 & 2.009 & Signifikan \\
\hline
\end{tabular}

Sumber: Hasil Pengolahan Data Eviews

Dengan tingkat signifikasi sebesar 95\% ( $\alpha=$ $0,05)$ dan derajat kebebasan (degree freedom) untuk $\mathrm{N}_{1}$ yang diperoleh $\mathrm{k}-1$ dan $\mathrm{N}_{2}$ diperoleh dari n-k, dimana $\mathrm{n}$ adalah banyaknya observasi dan $\mathrm{k}$ adalah jumlah parameter, didapat $\mathrm{N}_{1}=5$ dan $\mathrm{N}_{2}=49$, sehingga diperoleh F-tabel sebesar 2,40. Dengan nilai F-stat sebesar $9719.726>2,40$, maka seluruh variabel 
bebas secara bersama-sama berpengaruh signifikan terhadap penyerapan tenaga kerja di industri rajutan Binong Jati.

Dari hasil perhitungan regresi diperloeh nilai koefisien determinasi ( $R$-square) sebesar 0.998993. Hal ini menunjukan bahwa 99\% dari perubahan penyerapan tenaga kerja (Y) dapat dijelaskan oleh perubahan-perubahan dalam variabel tingkat upah $(\mathrm{W})$, volume penjualan $(\mathrm{V})$, harga bahan baku $(\mathrm{P})$, produktivitas (F) dan mesin (M), sedangkan sisanya sebesar $1 \%$ disebabkan oleh perubahan variabelvariabel lain di luar model.

\section{PEMBAHASAN}

\section{Kondisi Unit Usaha Sentra Industri Rajutan Binong Jati}

Pada awal Tahun 1975, jumlah perusahaan rajut yang ada hanya 3 unit usaha. Namun karena permintaan produk rajutan semakin meningkat, maka penduduk lainnya tertarik untuk mengembangkan usaha rajut tersebut. Pada akhirnya, di tahun 1999 jumlah usaha rajut di kawasan Binong berkembang menjadi 225 unit usaha. Perkembangan Sentra Industri Rajutan Binong Jati tidak selamanya menunjukkan peningkatan. Berdasarkan data yang dihimpun, pada tiga tahun terakhir (tahun 2012 sampai 2014), perkembangan Sentra Industri Rajutan Binong Jati justru mengalami penurunan. Pada tiga tahun tersebut Sentra Industri Rajutan Binong Jati mengalami penurunan baik dalam jumlah unit usaha maupun dalam jumlah pekerja yang dapat terserap pada sentra industri tersebut.

Sentra Industri Rajutan Binong Jati termasuk dalam industri padat karya. Berdasarkan hasil survei dari 55 unit usaha, unit-unit usaha yang ada di sentra industri rajutan Binomg Jati sebagian besar dapat diklasifikasikan sebagai kategori usaha kecil dan menengah karena $86 \%$ dari unit usaha yang disurvei memperkerjakan kurang dari 20 orang tenaga kerja, sisanya $14 \%$ unit usaha memperkerjakan lebih dari 20 orang.

Dilihat dari komposisi tenaga kerja yang bekerja di Sentra Industri Rajutan Binong Jati sebagian besar lulusan SLA dan SLTP. Selain itu untuk bekerja pada industri ini tidak memerlukan kualifikasi pendidikan tertentu, tetapi cukup dengan memiliki keterampilan membuat rajutan, bahkan tidak sedikit di antaranya yang memperoleh keterampilan tersebut dari pengalaman mereka selama bekerja.
Dengan jumlah pekerja sebagian besar di bawah 20 orang dan berbekal pendidikan SMA dan SMP, setiap pekerjanya memiliki produktivitas yang berbeda-beda. Namun secara umum dari hasil survei 55 unit usaha, sebagian besar tingkat produktivitas tenaga kerjanya berkisar antara 6 sampai 25 lusin per orang per bulannya. Tingkat produktivitas ini tentunya sangat ditentukan oleh tingkat keterampilan pekerja. Tingkat keterampilan pekerja pada umumnya akan terus meningkat sesuai dengan lamanya mereka bekerja pada bidang tersebut.

Pembagian kerja biasanya disesuaikan dengan jenis pekerjaan yang dilakukan saat produksi seperti merajut benang menjadi kain menggunakan mesin rajut, menyambung kain menggunakan mesin linking, mengobras, menyetrika dengan setrika steam uap sampai membersihkan benang-benang dari baju yang telah dijahit hingga packing hasil produksi. Para pekerja di Sentra Industri Rajutan Binong Jati mayoritas adalah laki-laki karena secara umum proses produksi membutuhkan tenaga yang besar, sedangkan untuk menjahit kancing, membersihkan benang-benang dari baju yang telah dijahit (Mensom), Quality Control (QC) dan Packing dilakukan oleh pekerja perempuan.

Proses produksi yang dilakukan pada industri rajut pada umumnya didukung dengan penyediaan mesin pada tiap unit usaha. Semakin banyak mesin yang dimiliki oleh suatu perusahaan maka semakin banyak pula tenaga kerja yang dibutuhkan untuk mengoperasikan mesin tersebut. Dari 55 unit usaha yang dijadikan sampel, sebanyak 45 unit usaha memiliki mesin antara 1 sampai 14 mesin.

Mesin yang digunakan dalam proses produksi ini merupakan mesin manual. Jadi setiap satu unit mesin membutuhkan satu orang pekerja untuk mengoperasikannya. Jumlah unit mesin yang dimiliki tidak semuanya dioperasikan. Berapa jumlah unit mesin yang dioperasikan tergantung dari jumlah produksinya. Berdasarkan wawancara dengan pemilik usaha, dikemukakan bahwa untuk kondisi saat ini dimana jumlah penjualan produk rajutan mengalami penurunan menyebabkan tidak semua mesin dapat dioperasikan.

Menurut hasil wawancara dengan unit-unit usaha yang disurvei, mereka mengatakan bahwa akhir-akhir ini volume penjualan mereka terus menurun. Pada kondisi saat penelitian, mereka menyebutkan bahwa volume penjualan mereka pada umumnya berkisar antara 50 sampai dengan 240 lusin per bulannya. Ada 
beberapa unit usaha yang dapat menjual lebih dari 240 lusin per bulannya.

Turunnya volume penjualan ini disebabkan karena berkurangnya permintaan konsumen. Penurunan permintaan ini salah satunya disebabkan karena munculnya barang-barang rajutan serupa yang diimpor dari luar negeri dengan harga yang lebih murah.

Para pengusaha rajutan di Sentra Industri Rajutan Binong Jati mengatakan bahwa mereka tidak bisa bersaing dalam harga dengan produk-produk rajutan impor karena harga bahan baku setiap tahunnya terus mengalami peningkatan. Selain itu juga mereka menghadapi kendala lainnya, misalnya dalam hal pemasaran dan permodalan.

Sentra Industri Rajutan Binong Jati memiliki organisasi yaitu Koperasi Sentra Industri Rajutan Binong Jati (KIRBI) merupakan salah satu organisasi para pemilik perusahaan rajutan yang berada di kawasan Sentra Industri Rajutan Binong Jati. Tujuan dari pendirian organisasi KIRBI yaitu untuk membantu menyelesaikan masalah para pengusaha rajutan misalnya dalam memasarkan produk-produk yang mereka hasilkan.

\section{Hubungan Antara Tingkat Upah dan Penyerapan Tenaga Kerja}

Berdasarkan hasil estimasi regresi koefisien variabel tingkat upah (W) mempunyai hubungan negatif dan tidak signifikan pengaruhnya terhadap penyerapan tenaga kerja di Sentra Industri Rajutan Binong Jati. Nilai koefisien variabel tingkat upah sebesar $-0,018468$, menjelaskan bahwa jika tingkat upah pada unit usaha meningkat sebesar $1 \%$ maka penyerapan tenaga kerja akan menurun sebesar $0,018 \%$.

Pengaruh negatif tingkat upah terhadap penyerapan tenaga kerja pada industri rajutan Binong sesuai dengan hipotesis penelitian. Dalam teori permintaan tenaga kerja disebutkan bahwa hubungan tingkat upah dengan permintaan tenaga kerja adalah negatif. Artinya jika upah meningkat maka permintaan tenaga kerjanya akan berkurang.

Hubungan positif dan signifikan antara tingkat upah dengan penyerapan tenaga kerja pada Sentra Industri Rajutan Binong Jati ini sejalan dengan hasil beberapa penelitian sebelumnya yang dilakukan pada beberapa industri kecil di berbagai daerah, seperti industri kecil tempe di Jepara (Yanuwardani dan
Woyanti, 2009), dan industri kecil menengah furniture di Jepara (Siburian dan Woyanti, 2013).

Adanya hubungan positif antara tingkat upah dan penyerapan tenaga kerja diperlihatkan juga dari beberapa penelitian yang dilakukan pada industri kecil menengah di luar negeri. Penelitian di Pakistan dengan objek penelitian industri kecil sektor manufaktur memperlihatkan bahwa semakin tinggi tingkat upah, maka permintaan tenaga kerja pada industri kecil sektor manufaktur ini semakin menurun (Khan, 2005). Hasil penelitian ini juga sejalan dengan hasil penelitian yang dilakukan terhadap petani di Benue State, Nigeria (Odoemenem dan Odom, 2010) dan penelitian di Provinsi Kohgiluyeh and BoyerAhmad, Iran (Namjou dan Moradi, 2015), yang keduanya menunjukkan bahwa tingkat upah pekerja berhubungan negatif dengan jumlah tenaga kerja yang dipekerjakan di kedua objek penelitian tersebut.

Walaupun tingkat upah mempunyai hubungan negatif dengan jumlah tenaga kerja yang terserap pada Sentra Industri Rajutan Binong Jati, namun dari hasil pengujian menunjukkan bahwa hubungan positif ini tidak signifikan. Tidak signifikannya hubungan antara tingkat upah dengan penyerapan tenaga kerja ini dikarenakan tenaga kerja yang dipakai adalah tenaga kerja yang tidak memerlukan keahlian khusus, bahkan banyak dari pekerja yang awal bekerja sama sekali tidak memiliki pengalaman dalam industri rajut. Sehingga posisi tawar tenaga kerja dalam menentukan upah sangat rendah. Tingkat upah ditentukan oleh pengusaha, besar kecilnya upah yang diterima tenaga kerja ditentukan oleh berapa banyak produk yang mereka hasilkan.

Pengaruh yang tidak signifikan tersebut tidak sesuai dengan penelitian yang telah dilakukan oleh Wijaya et al. (2014). Hasil penelitiannya mengemukakan bahwa tingkat upah berpengaruh tidak signifikan terhadap penyerapan tenaga kerja di Provinsi Riau.

\section{Pengaruh Volume Penjualan terhadap Penyerapan Tenaga Kerja}

Berdasarkan hasil estimasi regresi koefisien variabel volume penjualan (V) mempunyai hubungan positif dengan nilai koefisien sebesar 0,9746. Hasil ini menunjukkan bahwa jika volume penjualan salah satu perusahaan mengalami peningkatan sebesar $1 \%$ dibandingkan perusahaan lain, maka penyerapan tenaga kerja akan meningkat sebesar $0,974 \%$. Pada 
uji parsial variabel volume penjualan menunjukan pengaruh yang signifikan terhadap penyerapan tenaga kerja. Artinya jika volume penjualan barang-barang rajutan yang dihasilkan oleh Sentra Industri Rajutan Binong Jati meningkat, maka jumlah tenaga kerja yang terserap juga akan bertambah.

Pengaruh volume penjualan terhadap penyerapan tenaga kerja pada industri rajutan Binong Jati yang signifikan sesuai dengan hipotesis penelitian. Sesuai dengan teori permintaan tenaga kerja yang menyebutkan bahwa permintaan tenaga kerja bersifat derived demand, artinya sedikit banyaknya jumlah tenaga kerja yang terseap pada suatu unit usaha ditentukan oleh sedikit banyaknya jumlah permintaan barang yang diproduksi oleh unit usaha tersebut.

Jumlah volume penjualan industri rajutan Binong Jati sangat berpengaruh terhadap penyerapan tenaga kerja. Apabila volume penjualan suatu perusahaan meningkat, maka unit-unit usaha harus menambah produksi. Pada umumnya produksi di unit-unit usaha Sentra Rajutan Binong Jati dilakukan sesuai dengan permintaan (order) konsumen. Penambahan produksi tentunya akan berdampak pada penambahan tenaga kerjanya.

Pengaruh positif dan signifikan tersebut sesuai dengan penelitian terdahulu yang dilakukan oleh Adrianto (2013) yang melakukan penelitian pada usaha kecil menengah industri kerupuk di Kelurahan Bangsal Kecamatan Bangsal Kabupaten Mojokerto. Hasilpenelitiannya menunjukkan bahwa nilai produksi berengaruh positif dan signifikan terhadap penyerapan tenaga kerja pada industri kerupuk tersebut. Penelitian sejenis lainnya yang menunjukkan adanya hubungan positif antara nilai produksi atau volume penjualan dengan penyerapan tenaga kerja adalah penelitian Yanuwardani dan Woyanti (2009), Purnomo (2013), Budiawan (2013); Amri et al. (2013), Khan (2005), serta penelitian Odoemenem dan Odom (2010).

\section{Pengaruh Harga Bahan Baku terhadap Penyerapan Tenaga Kerja}

Berdasarkan hasil estimasi regresi koefisien variabel Harga Bahan Baku (P) mempunyai hubungan yang positif dengan nilai koefisien sebesar 0,00475. Nilai koefisien ini menunjukkan bahwa unit usaha yang membeli bahan baku secara tunai dapat menyerap tenaga kerja 0,476\% lebih banyak dari unit usaha yang membeli bahan baku secara kredit. Nilai 0,476 diperoleh dari antilog 0,00475, kemudian dikurangi 1 dikali 100 (Gujarati, 1995). Pada uji parsial variabel harga bahan baku menunjukan pengaruh yang tidak signifikan terhadap penyerapan tenaga kerja. Hal tersebut dibuktikan dengan hasil probabilitasnya sebesar 0,277 atau lebih dari $\alpha=5 \%$.

Adanya perbedaan jumlah penyerapan tenaga kerja pada unit usaha yang membeli bahan baku secara tunai dengan yang membeli secara kredit dapat dipahami karena perbedaaan cara pembelian bahan baku tersebut berdampak pada perbedaan harga bahan baku yang dibeli. Harga bahan baku secara tunai lebih murah dibandingkan secara kredit. Namun perbedaan harga bahan baku ini tidak terlalu besar. Hal inilah yang menyebabkan mengapa variabel harga bahan baku menjadi tidak signifikan dalam mempengaruhi penyerapan tenaga kerja di Sentra Industri Rajutan Binong Jati.

Penelitian ini berbeda dengan penelitian tentang penyerapan tenaga kerja lainnya yang menggunakan variabel harga bahan baku sebagai varaiabel bebas. Penelitian terdahulu menggunakan harga nominal dari bahan baku yang dipakai pada usaha-usaha yang menjadi objek penelitian (Odoemenem dan Odom, 2010), sedangkan pada penelitian ini menggunakan variabel dummy untuk membedakan harga bahan baku secara tunai dan secara kredit. pembelian. Walaupun terdapat perbedaan dalam penggunaan jenis data untuk harga bahan baku, namun hasil penelitian ini menunjukkan hasil sama dengan penelitian terdahulu yang memperlihatkan bahwa harga bahan baku tidak signifikan mempengaruhi penyerapan tenaga kerja pada unit usaha yang diteliti.

\section{Pengaruh Produktivitas terhadap Penyerapan Tenaga Kerja}

Berdasarkan hasil estimasi regresi koefisien variabel produktivitas tenaga kerja (F) mempunyai hubungan yang negatif sebesar $-0,978$, artinya jika produktivitas tenaga kerja mengalami peningkatan sebesar $1 \%$ maka penyerapan tenaga kerja akan menurun sebesar $0,978 \%$. Pada uji parsial variabel produktivitas tenaga kerja menunjukan pengaruh yang signifikan terhadap penyerapan tenaga kerja. Hal tersebut dibuktikan dengan hasil probabilitasnya sebesar 0,029 atau kurang dari $\alpha=5 \%$.

Pengaruh produktivitas tenaga kerja terhadap penyerapan tenaga kerja pada industri rajutan Binong Jati yang signifikan sesuai dengan hipotesis penelitian. Tinggi rendahnya produktivitas tenaga 
kerja maka akan berpengaruh terhadap penyerapan tenaga kerja. Jika seorang tenaga kerja dalam suatu perusahaan mampu menghasilkan produk secara produktif maka kebutuhan perusahaan akan tenaga kerja menjadi berkurang dan penyerapan tenaga kerja akan ikut menurun. Produktif dapat diartikan bahwa tenaga kerja dapat menghasilkan lebih banyak output maka tidak perlu menambah tenaga kerja baru.

Pengaruh positif dan signifikan dari variabel produktivitas tenaga kerja pada penyerapan tenaga kerja tersebut sesuai dengan penelitian terdahulu yang dilakukan oleh Siburian dan Woyanti (2013). Penelitian tersebut dilakukan dengan objek penelitian pengusaha kecil dan menengah industri furniture kayu di Kabupaten Jepara.

\section{Pengaruh Penggunaan Mesin terhadap Penyerapan Tenaga Kerja di Industri Rajutan Binong Jati}

Berdasarkan hasil estimasi regresi koefisien variabel penggunaan mesin (M) mempunyai hubungan yang positif dengan nilai koefisien sebesar 0,030. Hubungan positif memiliki arti jika penggunaan mesin bertambah $1 \%$ maka penyerapan tenaga kerja akan meningkat sebesar $0,030 \%$. Pada uji parsial variabel mesin menunjukan pengaruh yang signifikan terhadap penyerapan tenaga kerja. Hal tersebut dibuktikan dengan hasil probabilitasnya sebesar 0,032 atau kurang dari $\alpha=5 \%$.

Penggunaan mesin berpengaruh secara signifikan terhadap penyerapan tenaga kerja pada Sentra Industri Rajutan Binong Jati. Hal ini menunjukkan bahwa sedikit banyaknya tenaga kerja yang dipekerjakan tergantung dari sedikit banyaknya jumlah mesin yang dimiliki oleh masing-masing unit usaha. Pada usaha rajutan ini tenaga kerja dan mesin bersifat saling melengkapi atau bersifat komplementer. Mesin rajutan dioperasikan secara manual oleh tenaga kerja. Tanpa adanya tenaga kerja mesin rajutan tidak dapat dioperasikan.

Penggunaan mesin dalam penelitian ini juga dapat mewakili variabel modal yang merupakan faktor produksi lain selain tenaga kerja dan bahan baku dalam satu proses produksi. Pada beberapa penelitian sejenis tentang penyerapan tenaga kerja penggunaa variabel modal atau mesin juga dipergunakan sebagai salah satu variabel bebas yang mempengaruhi penyerapan tenaga kerja. Dari beberapa penelitian sebelumnya yang dirujuk, ada penelitian yang menunjukkan modal tidak signifikan mempengaruhi penyerapan tenaga kerja (Adrianto, 2013; Purnomo, 2013), sedangkan penelitian lainnya memperlihatkan hasil bahwa modal secara signifikan berpengaruh positif terhadap penyerapan tenaga kerja (Yanuwardani dan Woyanti, 2009; Siburian dan Woyanti, 2013; Budiawan, 2013; Khan, 2005).

\section{KESIMPULAN}

Unit-unit usaha yang ada di Sentra Industri Rajutan Binong Jati termasuk dalam kategori usaha kecil dan menengah dengan sifat padat karya (labor intensive). Dalam jumlah tenaga kerja yang terserap, Sentra Industri Rajutan Binong Jati menempati posisi kedua terbanyak setelah Sentra Sepatu Cibaduyut. Walaupun penyerapan tenaga kerja pada Sentra Industri Rajutan Binong Jati ini cukup potensial, namun dalam beberapa tahun terakhir kondisinya mengalami penurunan. Hal ini dapat dilihat dari jumlah unit usaha dan jumlah pekerja yang menurun. Kondisi penururan ini disebabkan karena akhirakhir ini penjualan produk rajutan Binong Jati terus berkurang. Salah satu penyebabnya adalah semakin banyaknya produk impor sejenis yang beredar di pasar dalam negeri dengan harga dan kualitas yang lebih baik.

Berdasarkan analisis regresi variabel tingkat upah berhubungan negatif dengan penyerapan tenaga kerja, sedangkan produktivitas tenaga kerja, volume penjualan, harga bahan baku dan jumlah unit mesin memiliki hubungan dengan penyerapan tenaga kerja. Dari hasil pengujian menunjukkan bahwa secara bersama-sama semua variabel bebas secara nyata berpengaruh terhadap penyerapan tenaga kerja. Secara parsial variabel upah dan harga bahan baku tidak signifikan mempengaruhi penyerapan tenaga kerja, sedangkan variabel volume penjualan, produktivitas tenaga kerja, dan jumlah unit mesin signifikan mempengaruhi penyerapan tenaga kerja.

Tidak signifikannya hubungan antara tingkat upah dengan penyerapan tenaga kerja ini dikarenakan tenaga kerja yang dipakai adalah tenaga kerja yang tidak memerlukan keahlian atau keterampilan khusus, sehingga posisi tawar tenaga kerja dalam menentukan upah sangat rendah. Tingkat upah ditentukan oleh pengusaha, besar kecilnya upah yang diterima tenaga kerja ditentukan oleh berapa banyak produk yang mereka hasilkan. 
Berapa banyak jumlah output yang dapat dihasilkan oleh seorang pekerja menggambarkan seberapa besar tingkat produktivitas pekerja tersebut. Semakin tinggi tingkat produktivitas tenaga kerja, semakin sedikit penyerapan tenaga kerja di unit-unit usaha rajutan tersebut. Kebutuhan jumlah pekerja akan semakin berkurang jika setiap pekerja dapat menghasilkan produk lebih banyak dengan periode yang sama.

Permintaan tenaga kerja pada Sentra Industri Rajutan Binong Jati bersifat derived demand, banyak sedikitnya ditentukan oleh berapa besar permintaan produk barang rajutan di pasar. Semakin banyak permintaan produk dari konsumen, semakin banyak produksinya, maka semakin banyak kebutuhan tenaga kerjanya.

Perbedaan dalam sistem pembelian bahan baku menimbulkan perbedaan harga bahan baku, walaupun perbedaannya tidak terlalu besar. Unit usaha yang membeli bahan baku secara tunai memperoleh harga beli bahan baku lebih murah, sehingga penyerapan tenaga kerjanya lebih banyak dari unit usaha yang membeli bahan baku secara kredit.

Mesin rajutan adalah modal utama dalam industri rajutan. Setiap mesin dioperasikan secara manual oleh pekerja. Berapa jumlah mesin yang dimiliki menunjukkan berapa besar modal yang dimiliki masing-masing unit usaha. Semakin banyak mesin yang dimiliki semakin besar kapasitas produksi unit usaha tersebut, semakin banyak juga pekerja yang dibutuhkan untuk mengoperasikan mesin tersebut.

\section{DAFTAR PUSTAKA}

Adrianto, Rizky. 2013. Analisis Faktor-Faktor Yang Mempengaruhi Penyerapan Tenaga Kerja Pada Industri Kecil: Studi Kasus Pada Industri Krupuk Rambak di Kelurahan Bangsal, Kecamatan Bangsal, Kabupaten Mojokerto. Jurnal Ilmiah Mahasiswa FEB Universitas Brawijaya Malang, 1(1).

Al Farisi, Raisan. 2013. Pengaruh Inovasi dan Kreativitas Pengusaha Terhadap Keberhasilan Usaha. Bandung: Universitas Pendidikan Indonesia.

Amri, Yassir, Abubakar Hamzah \& Sofyan Syahnur. 2013. Peran Industri Mikro dan Kecil dalam Penyerapan Tenaga Kerja di Provinsi Aceh. Jurnal Ilmu Ekonomi Pascasarjana Universitas Syiah Kuala, 1(1): 77-85.
Biniaz, Arsalan, Behrooz Hassanpour \& Esa Asadi. 2014. Labor Productivity and Factors Affecting its Demand in Paddy Farms in KB Province, Iran. Agriculture Science Developments, 3(7): 251-255.

Budiawan, Amin. 2013. Faktor-faktor yang Mempengaruhi Penyerapan Tenaga Kerja terhadap Industri Kecil Pengolahan Ikan di Kabupaten Demak. Economics Development Analysis Journal, 2(1).

Gujarati, Damodar N. 1995. Basic Econometrics (3 ${ }^{\text {rd }}$ edition). Singapore: McGraw-Hill.

Khan, Javaid Iqbal. 2005. Intra-Model Employment Elasticities: A Case Study of Pakistan's Small Scale Manufacturing Sector. The Labore Journal of Economics, 10(1): 141-153.

Namjou, Sadegh \& Mehrdad Moradi. 2015. Factors Affecting Labor Demand in Kohgiluyeh and Boyer-Ahmad Province. International Journal of Review in Life Sciences, 5(6): 297-302.

Odoemenem, I. U. \& L. N. Odom. 2010. Some Factors Affecting the Demand for Hired Labor: A Case Study of Maize Farmers of Benue State, Nigeria. Current research Journal of Social Sciences 2(6): 322-326.

Purnomo, Reza Adi. 2013. Analisis Variabel-Variabel yang Mempengaruhi Penyerapan Tenaga Kerja pada Usaha Kecil dan Menengah Anyaman Bambu di Kabupaten Banyuwangi, Jawa Timur. Jurnal Ilmiah Mahasiswa FEB Universitas Brawijaya Malang, 1(2).

Siburian, Vera Haryani \& Nenik Woyanti. 2013. Analisis Penyerapan Tenaga Kerja pada Industri Kecil dan Menengah: Studi Kasus pada Industri Kecil Menengah Furniture Kayu di Kabupaten Jepara. Diponegoro Journal of Economics, 2(4): $1-9$.

Simanjuntak, Payaman J. 2001. Pengantar Ekonomi Sumber Daya Manusia. Jakarta: Fakultas Ekonomi UI.

Umar, Husein. 2011. Metode Penelitian Untuk Skripsi Dan Tesis Bisnis. Jakarta: RajaGrafindo Persada.

Wijaya, Andi, Toti Indrawati \& Eka Armas Pailis. 2014. Analisis Faktor-Faktor yang Mempengaruhi Penyerapan Tenaga Kerja di Provinsi Riau. JOM Fekon, 1(2).

Yanuwardani, Dian W. \& Nenik Woyanti. 2009. Analisis Pengaruh Faktor Ekonomi terhadap Penyerapan Tenaga Kerja pada Industri Kecil Tempe di Kota Semarang. Media Ekonomi dan Manajemen, 20(2): 190-201. 